\title{
Infections after cardioverter-defibrillator implantation: observations in 335 patients over 10 years
}

\author{
Hans-Joachim Trappe, Petra Pfitzner, Helmut Klein, Paul Wenzlaff
}

\begin{abstract}
Objective-To determine the incidence of infection after implantation of a cardioverter-defibrillator and the management of this complication.

Subjects-335 consecutive patients who had a cardioverter-defibrillator implanted between January 1984 and December 1993. Main outcome measures-Incidence of infection within the first month after implantation (early infection) and after the first month (late infection).

Results-Infections associated with cardioverter-defibrillator devices occurred in 13 patients (3.9\%) during a mean follow up of 22 (11) months. All patients had general signs of inflammation, fever $\left(>37 \cdot 5^{\circ} \mathrm{C}\right)$, and leucocytosis $(>10000 / \mathrm{ml})$ with or without purulent drainage. Five patients $(38 \%)$ had infections during the first implantation, whereas eight patients $(62 \%)$ had infections after replacement of the pulse generator. Early infection was observed in four patients $(31 \%)$ and late infection in nine $(69 \%)$. Incidence of infection was higher in patients who underwent epicardial cardioverter-defibrillator implantation (12/207 patients, $5.8 \%$ ) than in those who received nonthoracotomy lead systems (1/125 patients, $0.8 \%)(P<0.05)$. Infections were caused by staphyloccocus in 10 patients, pseudomonas in two patients, and streptococcus in one patient. The whole device had to be removed in all patients. During a mean follow up of 39 (29) months seven patients died: six of congestive heart failure and one of myocardial reinfarction. Conclusions-Infection, one of the most serious complications after cardioverterdefibrillator implantation, is associated with increased morbidity and mortality. When infection occurs the system must be removed to avoid a fatal outcome.
\end{abstract}

Department of Cardiology,

University Hospital,

Hanover, Germany

H-J Trappe

P Pfitzner

H Klein

P Wenzlaff

Correspondence to:

Dr Hans-Joachim Trappe,

Department of Cardiology,

University Hospital,

Hanover 30625, Hanover,

Germany.

Accepted for publication

18 July 1994 cardioverter-defibrillators has increased exponentially, more than 25000 patients having received this device during the past 12 years. ${ }^{4}$ Despite excellent results in preventing sudden death there are few reports about complications due to operative mortality, electrodes, or other causes. ${ }^{5-7}$ Infection is one of the most serious complications and is associated with morbidity, prolonged stay in hospital, and death. ${ }^{8}$ We report on the infection rate, diagnosis, management, and follow up in 335 patients who had a cardioverter-defibrillator implanted over a period of 10 years.

\section{Patients and methods}

PATIENTS

We followed up 335 consecutive patients (304 males and 31 females, mean age 56 (11) years (range 10 to 78 years)) who had a cardioverter-defibrillator implanted between January 1984 and December 1993. Spontaneous episodes of sustained ( $>30 \mathrm{~s}$ ) ventricular tachycardia or ventricular fibrillation occurred in 319 patients (95\%), and 16 patients $(5 \%)$ had a cardioverter-defibrillator implanted according to the protocol of the multicentre automatic defibrillator implantation trial or the cardiomyopathy trial. ${ }^{910}$ All patients were considered candidates for cardioverter-defibrillator implantation on the basis of their history and the presence of spontaneous and inducible ventricular tachyarrhythmias. ${ }^{11}$

\section{IMPLANTATION PROCEDURE}

The cardioverter-defibrillator was implanted under general anaesthaesia from the beginning using epicardial (207 patients, $62 \%$ ) or nonthoracotomy implantation techniques (125 patients, 38\%) as previously described. ${ }^{12} 13$ Patients with an epicardial implantation underwent median sternotomy; two screw in electrodes were placed on the anterior aspect of the right ventricle and two patch electrodes were attached with fibrin glue in inferior and anterolateral positions on the left ventricle. Non-thoracotomy defibrillation lead systems were inserted into the left subclavian vein through a small incision over the delto pectoral groove. Under fluoroscopic guidance the tip of the Endotak electrode (Cardiac Pacemakers, St Paul, Minnesota, USA) was placed in the apex of the right ventricle and the proximal coil positioned in the right atrium near to the junction of the right atrium and superior vena cava. In the first 65 patients non-thoracotomy defibrillation lead systems were implanted in the operating theatre; since May 1993, 57 consecutive patients have received non-thoracotomy devices in a catheter laboratory. The pulse generator was 
placed in the left upper abdomen under the rectus muscle using both thoracotomy and non-thoracotomy techniques. Generators were replaced under general anaesthesia, as previously described. ${ }^{14}$ Intraoperative testing was performed to ensure an acceptable pacing threshold, sensing of ventricular tachycardia or ventricular fibrillation, and effective cardioversion or defibrillation.

Antibiotic prophylaxis was started at implantation: The electrodes were rinsed in antibiotic solution (neomycin) before the device was implanted and patients were given cephazolin intravenously during the operation and cephazolin $2 \mathrm{~g}$ twice daily for three days. Drains were always inserted (after implantation and replacement of the pulse generator) and were usually removed on the first or second postoperative day.

\section{MEDICAL HISTORY}

Nine patients had coronary artery disease, two dilated cardiomyopathy, and two right ventricular dysplasia. The mean left ventricular ejection fraction was $32 \%(10 \%)$ (range 15-55\%) (table 1). A cardioverter-defibrillator was implanted after sternotomy with epicardial patch electrodes in 12 patients, whereas non-thoracotomy defibrillation lead systems were implanted in one patient. Six patients had coronary artery bypass grafting, one patient before implantation of a cardioverter-defibrillator and five patients during implantation of a first device.

DIAGNOSIS

Infection after implantation was suspected in the presence of local and general signs of inflammation. Clinical manifestations depend on the site affected and the time since the operation. Infection was diagnosed if general signs of inflammation were present, such as fever $\left(>37.5^{\circ} \mathrm{C}\right)$, leucocytosis $(>10000 / \mathrm{ml})$, a shift of the differential blood count to the left, raised serum $C$ reactive protein concentration, and detection of microorganisms in blood cultures. Since most infections occur around the pulse generator pocket, local signs of warmth, erythema, and purulent drainage, sometimes with fluctuation, were present.

FOLLOW UP

All patients were followed up in the outpatient clinic every two months. During these visits, in addition to routine clinical evaluation, the cardioverter-defibrillator was examined in detail. All patients were asked to contact this hospital immediately if signs of inflammation, fever, or erythema or warmth of the generator pocket developed.

STATISTICAL ANALYSIS

All variables were expressed as means (SD). Significance was evaluated by Fisher's two sided exact test. $P$ values $<0.05$ were considered to be significant.

\section{Results}

INCIDENCE OF INFECTIONS

During a mean follow up of 22 (11) months (range $<1$ to 112 months), infections occurred in 13 patients $(3.9 \%)$ despite antibiotic prophylaxis. All were men and their mean age was 58 (11) (range 39 to 74). All patients had general signs of inflammation, local infections, and microorganisms in a blood culture. Most patients (10/13 patients, $77 \%)$ had staphylococci ( $S$ aureus or coagulase negative species); pseudomonas was present in two patients $(15 \%)$ and Streptococcus pyogenes in one patient $(8 \%)$. Interestingly, infections occurred more frequently in patients who had a pulse generator replaced (8/13 patients,

Characteristics of 13 patients who developed infection after implantation of cardioverter-defibrillator

\begin{tabular}{|c|c|c|c|c|c|c|c|c|c|c|c|}
\hline $\begin{array}{l}\text { Case } \\
\text { no }\end{array}$ & $\begin{array}{l}\text { Age } \\
\text { (years) }\end{array}$ & Sex & Underlying disease & $\begin{array}{l}\text { Left } \\
\text { ventricular } \\
\text { ejection } \\
\text { fraction } \\
(\%)\end{array}$ & $\begin{array}{l}\text { Class } \\
\text { of heart } \\
\text { failure }\end{array}$ & Operation & Organism & $\begin{array}{l}\text { Temperature } \\
\left({ }^{\circ} \mathrm{C}\right)\end{array}$ & $\begin{array}{l}\text { Leucocytes } \\
(\mid \mathrm{ml})\end{array}$ & $\begin{array}{l}\text { Time } \\
\text { between } \\
\text { operation } \\
\text { and infection } \\
\text { (months) }\end{array}$ & Outcome \\
\hline 1 & 45 & $\mathbf{M}$ & $\begin{array}{l}\text { Right ventricular } \\
\text { dysplasia }\end{array}$ & 35 & I & 3.ICD & $\begin{array}{l}\text { Coagulase negative } \\
\text { staphylococci }\end{array}$ & $40 \cdot 2$ & 21800 & 18 & \\
\hline 2 & 60 & $\mathbf{M}$ & $\begin{array}{l}\text { Coronary artery } \\
\text { disease }\end{array}$ & 31 & II-III & 1.ICD & Staph aureus & $38 \cdot 5$ & 17500 & $<1$ & New implantation \\
\hline 3 & 59 & $\mathbf{M}$ & $\begin{array}{l}\text { Coronary artery } \\
\text { disease }\end{array}$ & 29 & II-III & 3.ICD & Staph aureus & $37 \cdot 5$ & 11800 & 2 & New implantation \\
\hline 4 & 66 & $\mathbf{M}$ & $\begin{array}{l}\text { Dilated } \\
\text { cardiomyopathy }\end{array}$ & 25 & II-III & 1.ICD & Pseudomonas & $37 \cdot 8$ & 18500 & $<1$ & Cardiac death \\
\hline 5 & 74 & $\mathbf{M}$ & $\begin{array}{l}\text { Coronary artery } \\
\text { disease }\end{array}$ & 55 & III & 1.ICD & $\begin{array}{l}\text { Coagulase negative } \\
\text { staphylococci }\end{array}$ & $39 \cdot 5$ & 14900 & $<1$ & \\
\hline 6 & 45 & $\mathbf{M}$ & $\begin{array}{l}\text { Coronary artery } \\
\text { disease }\end{array}$ & 30 & II-III & 2.ICD & Pseudomonas & 38.9 & 21200 & 18 & Cardiac death \\
\hline 7 & 62 & $\mathbf{M}$ & $\begin{array}{l}\text { Coronary artery } \\
\text { disease }\end{array}$ & 26 & III & 3.ICD & $\begin{array}{l}\text { Coagulase negative } \\
\text { staphylococci }\end{array}$ & $36 \cdot 6$ & 9700 & 4 & $\begin{array}{l}\text { New implantation, } \\
\text { Cardiac death }\end{array}$ \\
\hline 8 & 49 & $\mathbf{M}$ & $\begin{array}{l}\text { Coronary artery } \\
\text { disease }\end{array}$ & 25 & II-III & 1.ICD & Staph aureus & $39 \cdot 5$ & 21000 & 12 & Cardiac death \\
\hline 9 & 68 & M & $\begin{array}{l}\text { Right ventricular } \\
\text { dysplasia }\end{array}$ & 41 & II-III & 1.ICD & $\begin{array}{l}\text { Coagulase negative } \\
\text { staphylococci }\end{array}$ & $35 \cdot 8$ & 26200 & 18 & $\begin{array}{l}\text { New implantation, } \\
\text { Cardiac death }\end{array}$ \\
\hline 10 & 66 & $\mathbf{M}$ & $\begin{array}{l}\text { Dilated } \\
\text { cardiomyopathy }\end{array}$ & 46 & III & 3.ICD & Staph aureus & $38 \cdot 5$ & 20500 & 3 & Cardiac death \\
\hline 11 & 41 & $\mathbf{M}$ & $\begin{array}{l}\text { Coronary artery } \\
\text { disease }\end{array}$ & 34 & II-III & 2.ICD & Staph aureus & $37 \cdot 4$ & 18700 & 2 & \\
\hline 12 & 52 & $\mathbf{M}$ & $\begin{array}{l}\text { Coronary artery } \\
\text { disease }\end{array}$ & 15 & III & 4.ICD & Staph aureus & $40 \cdot 1$ & 29500 & 4 & Cardiac death \\
\hline 13 & 69 & $\mathbf{M}$ & $\begin{array}{l}\text { Coronary artery } \\
\text { disease }\end{array}$ & 25 & II & 3.ICD & Str pyogenes & $37 \cdot 8$ & 16500 & $<1$ & \\
\hline
\end{tabular}

^New York Heart Association's classification.

1.ICD, first implantation. 2.ICD, first replacement, but ICD generator number 2. 
$62 \%)$ compared with patients with first cardioverter-defibrillator implantation (5 of 13 patients, 38\%). Early infection (within 1 month) occurred in four out of 13 patients $(31 \%)$. In contrast, nine out of 13 patients (69\%) had late ( $>1$ month) infection. Infections occurred in 12 out of 207 patients $(5 \cdot 8 \%)$ who underwent epicardial implantation compared with one of the 125 patients $(0.8 \%)$ who received non-thoracotomy defibrillation lead systems $(P<0.05)$.

\section{CLINICAL FINDINGS}

Infections were associated with fever $\left(>37.5^{\circ} \mathrm{C}\right)$ in 11 of the 13 patients $(85 \%)$ and leucocytosis $(>10000 / \mathrm{ml})$ in 12 of them $(92 \%)$. All had blood cultures positive for micro-organisms. Infections were localised in the pulse generator pocket in all of them. These findings led to the diagnosis of infection. Pathological findings around the defibrillator patch electrodes (fluid around the patches) were present in one patient (8\%), but this patient also had purulent drainage of the pulse generator pocket. In all patients clinical findings were, without any doubt, that of infection.

\section{TREATMENT}

On admission all patients were treated immediately by systemic antibiotics. However, in all patients it was necessary to remove the cardioverter-defibrillator system within a mean of 3 (2) days (range $<1$ to 7 days) after admission. In 12 of the 13 patients $(92 \%)$ the electrodes and the pulse generator were removed, and in one patient ( $8 \%$ ) with circumscribed pathological findings around the pocket, the pulse generator was removed but the electrodes were not. After removal of the entire cardioverter-defibrillator system, systemic antibiotic treatment was continued for three to four weeks and followed by oral antibiotics for at least three months. One to three months after removal patients were considered for repeated device implantation if they had no signs of inflammation.

\section{FOLLOW UP}

Seven of the 13 patients (54\%) died during a mean follow up of 39 (29) months (range <1 to 108 months) in patients who had infections. The cause of death was heart failure in six patients and myocardial reinfarction in one patient (case 7, table). Reimplantation was performed in four patients and one patient has remained in hospital (case 13, table). Three patients refused reimplantation of the cardioverter-defibrillator, and these patients have remained well. In these patients who have been followed up for a mean of 28 (23) months (range 13 to 55), no further infections have occurred.

\section{Discussion}

Infection of the pulse generator pocket or the defibrillation lead system, or both, is one of the most serious complications of treatment with a cardioverter-defibrillator. ${ }^{581516}$ It results in increased morbidity, mortality, and stay in hospital. Usually, the removal of pulse generator and defibrillation system is necessary to cure this complication and to avoid death. ${ }^{17} 18$

\section{INCIDENCE OF INFECTIONS}

The incidence of any type of perioperative infection ranged from 0 to $16 \%$, and infections due to the hardware of the implanted device hardware occurred in $0-7 \cdot 2 \%$ of patients. ${ }^{19-23}$ We found an overall infection rate of $3.9 \%$. We found that infections occurred more commonly after replacement of the pulse generator than after first implantation of a cardioverter-defibrillator system. Late infection was more common than early infection after device implantation or pulse generator replacement. In addition, it is important to note that infections occurred significantly less often in patients with non-thoracotomy devices $(0.8 \%)$ than in those after epicardial cardioverter-defibrillator implantation $(5.8 \%)(P<0.05)$.

\section{PATHOGENESIS OF INFECTIONS}

The pathogenesis of infection is still unclear, but it seems reasonable to divide it into early or late occurrence. Early infection, like pacemaker infections, is most commonly caused by staphylococci, which is in agreement with previous data. ${ }^{7}$ Contamination of the device by bacteria possibly occurs during the operation and infection may therefore appear soon after implantation. However, this is influenced by other factors such as the number and virulence of micro-organisms and factors influencing the host's defence. ${ }^{24}$ Infections occurred late and after replacement of a pulse generator in most of our patients. The pathogenesis of late infection is either bacteriaemia or delayed onset of infection acquired soon after surgery. However, another possible explanation for late infection and a high infection rate after replacement of pulse generators might be the formation of fibrous tissue around the pulse generator with decreased circulation. ${ }^{25}$

\section{DIAGNOSIS}

Diagnosis of infection is usually possible from local or general signs of inflammation, or both. However, it is sometimes difficult to decide whether a manifest infection is present, particularly if local pathological findings around the pulse generator (fluctuation) are present without fever, leucocytosis, or purulent drainage. In patients with suspected infection adequate management is difficult. ${ }^{78}$ We found that clinical variables such as fever, leucocytosis, a shift of the differential count to the left, and positive blood culture were present and pointed to infection without the need for other diagnostic procedures.

The role of diagnostic methods such as echocardiography, chest radiography, computer tomography, and gallium scintigraphy in diagnosing infections of the device is controversial. ${ }^{202627}$ In cases of suspected infection "crumpling" (deformation of the radiopaque 
wire marker around the patch perimeter) of one or both patch electrodes may occur ${ }^{7}$; in another study, however crumpling was observed in $21 \%$ of patch electrodes in 51 patients with an uncomplicated clinical course after implantation of a cardioverter-defibrillator.

The use of gallium scintigraphy to detect infection has been suggested by Kelly et al, who found that the technique detected all cases of infected devices in their patients. ${ }^{20}$ However, Bakker et al described false positive results in non-infected healing wounds. ${ }^{8}$ Therefore, a final conclusion about the value of this method is not possible at the moment.

Computed tomography is helpful in identifying patients with problems after cardioverter-defibrillator implantation. ${ }^{728}$ However, detection of infection by this method is often difficult and fluid often occurs around patch electrodes after implantation, particularly within the perioperative period. ${ }^{22}$ Fluid collects between patch electrodes and epicardium in $4-5 \%$ of patients and is an unusual finding. ${ }^{8}$

\section{TREATMENT}

There are several possible treatments for infections occurring after implantation of a cardioverter-defibrillator or replacement of a pulse generator: drug treatment (courses of systemic antibiotics), removal of the pulse generator in combination with drug treatment, and complete removal of the cardioverter-defibrillator system (electrode leads and pulse generator).

Although it may occasionally be possible to treat infected devices with systemic antibiotic drug treatment, we favour removal of the complete system, as suggested by others. ${ }^{8} \mathrm{We}$ believe that removal of the cardioverter-defibrillator system will cure infection and will avoid serious complications such as sepsis and death. We found that mortality in patients with infections after cardioverter-defibrillator implantation is high. Therefore, if infections occur the hardware should be removed immediately. We believe that systemic antibiotics will not cure infection in these patients and that antibiotics should be used before and after removal of the cardioverter-defibrillator system. We strongly recommend not delaying removal of the device because drug treatment will not prevent sepsis or death. However, conservative treatment in addition to removal of only the pulse generator may be successful in selected cases. ${ }^{29}$

\section{CLINICAL IMPLICATIONS}

Infection is one of the most serious complications of cardioverter-defibrillators. If infection occurs, morbidity, mortality, and stay in hospital increase. In general, occurrence of infections after implantation is fairly low, particularly after implanting transvenous defibrillation lead systems. Infection leads to clinical signs of inflammation and local findings of warmth and erythema with or without purulent drainage. There is an increased risk after replacement of a pulse generator, infec- tions more often being delayed. Therefore, patients need to be surveyed to avoid infection. If infection occurs they should be treated immediately. We believe that systemic antibiotics are only adjunctive treatment; patients who develop infections after having a cardioverter-defibrillator implanted should have all the hardware removed as soon as possible to avoid further complications or death.

We thank Mrs Julie Grefe for her help in preparing the manuscript.

1 Mirowski M, Reid P, Mower M, Watkins L, Gott VL, Schauble JF, et al. Termination of malignant ventricular arrhythmias with an implanted automatic defibrillator in human beings. $N$ Engl $\mathscr{f}$ Med 1980;303:322-4

2 Reid PR, Griffith LSC, Platia EV, Mower MM, Veltri EP, Mirowski $\mathrm{M}$, et al. The automatic implantable cardioverter defibrillator: five-year clinical results. In: Breithardt G, Borggrefe M, Zipes DP, eds. Nonpharmacological therapy of tachyarrhythmias. Mount Kisco, New York: Futura: 1987:477-86.

3 Akhtar M, Jazayeri MR, Sra JS, Dhala A, Deshpande S, Blanck Z, et al. Implantable cardioverter-defibrillator therapy for prevention of sudden cardiac death. In: therapy for prevention of sudden cardiac death. In: Akhtar M, ed. Cardiology
Saunders, 1993:97-108.

4 Nisam S, Mower MM, Thomas A, Hauser R. Patient survival comparison in three generations of automatic implantable cardioverter defibrillators: review of 12 years, 25,000 patients. Pacing Clin Electrophysiol 1993; 16:174-8.

5 Grimm W, Flores B, Marchlinski FE. Complications of implantable cardioverter defibrillator therapy: follow-up of 241 patients. Pacing Clin Electrophysiol 1993;16: 218-22.

6 Trappe HJ, Klein H, Fieguth HG, Wenzlaff P, Lichtlen $\mathrm{PR}$. Problems and complications after implantation of the automatic cardioverter-defibrillator. Med Klin 1993; 88:619-28.

7 Troup P, Nisam S. Complications associated with the automatic implantable cardioverter defibrillator. In: Alt E, Klein H, Griffin JC, eds. The implantable cardioverter defibrillator. Berlin: Springer, 1992:253-71.

8 Bakker PFA, Hauer RNW, Wever EFD. Infections involving implanted cardioverter defibrillator devices. Pacing Clin Electrophysiol 1992;15:654-8.

9 Moss AJ. Prospective antiarrhythmic studies assessing prophylactic pharmacological and device therapy in high risk coronary patients. Pacing Clin Electrophysiol 1992; 15:694-6.

10 Cardiomyopathy Trial Investigators: Cardiomyopathy trial. Pacing Clin Electrophysiol 1993;16:576-81.

11 Trappe HJ, Klein H, Wenzlaff P, Frank G, Siclari F, Götte $A$, et al. Ventricular tachycardia surgery in 1992: Did the automatic defibrillator change this approach? Pacing Clin Electrophysiol 1993;16:242-6.

12 Siclari F, Klein H, Trappe HJ. Surgical techniques of defibrillator implantation. In: Alt E, Klein H, Griffin JC, eds. The implantable cardioverter defibrillator. Berlin: Springer, 1992:242-52.

13 Trappe HJ, Klein H, Fieguth HG, Kielblock B, Wenzlaff $P$, Lichtlen PR. Initial experience with a new transvenous defibrillation system. Pacing Clin Electrophysiol 1993;16:134-40.

14 Frank G, Lowes D. Implantable cardioverter defibrilaltors: surgical considerations. Pacing Clin Electrophysiol 1992; 15:631-5.

15 Siclari F, Klein H, Trappe HJ, Borst HG. Infectious complications after AICD implantation [abstract]. Pacing Clin Electrophysiol 1990;13:547.

16 Almassi GH, Olinger GN, Troup PJ, Goodman LR. Delayed infection in the automatic implantable cardioverter/defibrillator. $\mathcal{F}$ Thorac Cardiovasc Surg 1988;95: 908-11.

17 Meesmann M. Factors associated with implantationrelated complications. Pacing Clin Electrophysiol 1992;15: 647-53.

18 Wunderly D, Maloney J, Edel T, McHenry M, McCarthy PM. Infections in implantable cardioverter defibrillator patients. Pacing Clin Electrophysiol 1990;13: 1360-4.

19 Winkle RA, Mead RH, Ruder MA, Gaudiani VA, Smith NA, Buch WS, et al. Long-term outcome with the automatic implantable cardioverter-defibrillator. $7 \mathrm{Am}$ Coll Cardiol 1989;13:1353-61.

20 Kelly PA, Cannom DS, Garan H, Mirabel GS, Harthorne $\mathrm{JW}$, Hurvitz RJ, et al. The automatic implantable cardioverter-defibrillator: efficacy, complications and survival in patients with malignant ventricular arrhythmias. $\mathfrak{f} \mathrm{Am}$ Coll Cardiol 1988;11:1278-86.

21 Tchou PJ, Kadri N, Anderson J, Caceres JA, Jazayeri M, Akhtar M. Automatic implantable cardioverter defibrillators and survival of patients with left ventricular dysfunction and malignant ventricular arrhythmias. Ann Intern Med 1988;109:529-34. 
22 Hargrove WC, Josephson ME, Marchlinkski FE, Miller JM. Surgical decisions in the management of sudden cardiac death and malignant ventricular arrhythmias. ¥ Thorac Cardiovasc Surg 1989;97:923-8.

23 Manolis AS, Tan-DeGuzman W, Lee MA, Rasteger H, Haffaje C Huang SKS et al. Clinical experience in Haffajee C, Huang SKS, et al. Clinical experience in seventy-seven patients with the automatic implantable

24 Christensen GD, Baddour LM, Hasty DL. Microbial an foreign body factors in the pathogenesis of medical foreign body factors in the pathogenesis of medical device infections. In: Bisno AL, Waldvogel FA, eds. Washington, DC: American Society for Microbiology, 1989:27-59.

25 Furman S. Implantable cardioverter defibrillator infection. Pacing Clin Electrophysiol 1990;13:1351.
26 Leppert A, Nolte C, Trappe HJ, Galanski M. Radiologic appearance and evaluation of the implantable cardioverter defibrillator (ICD). Radiologe 1992;32. 541-5.

27 Goodman LR, Almassi GH, Troup PJ, Gurney JW, Veseth-Rogers J, Chapman PD, et al. Complications of automatic implantable cardioverter defibrillators: radiographic, CT, and echocardiographic evaluation. graphic, CT, and echocardiographic evaluation
Radiology 1989;170:447-52. 28 Siclari $\mathrm{F}$ Klein $\mathrm{H}$, Tröster J. Intraventricular migration of an ICD patch. Pacing Clin Electrophysiol 1990;13: an ICD patch. Pacing Clin Electrophysiol 1990;13:

29 Taylor RI Cohen DJ, Widman LE, Chilton RJ, O'Rourke RA. Infection of an implantable cardioverter-fibrillator: management without removal of the device in selected cases. Pacing Clin Electrophysiol 1990;13:1352-5. 